\title{
THE NUCLEATION OF MICROTUBULES IN Aspergillus nidulans GERMLINGS
}

\author{
Cristina de Andrade-Monteiro and Nilce M. Martinez-Rossi
}

\begin{abstract}
Microtubules are filaments composed of dimers of alpha- and beta-tubulins, which have a variety of functions in living cells. In fungi, the spindle pole bodies usually have been considered to be microtubule-organizing centers. We used the antimicrotubule drug Benomyl in block/release experiments to depolymerize and repolymerize microtubules in Aspergillus nidulans germlings to learn more about the microtubule nucleation process in this filamentous fungus. Twenty seconds after release from Benomyl short microtubules were formed from several bright (immunofluorescent) dots distributed along the germlings, suggesting that microtubule nucleation is randomly distributed in $A$. nidulans germlings. Since nuclear movement is dependent on microtubules in $A$. nidulans we analyzed whether mutants defective in nuclear distribution along the growing hyphae (nud mutants) have some obvious microtubule defect. Cytoplasmic, astral and spindle microtubules were present and appeared to be normal in all nud mutants. However, significant changes in the percentage of short versus long mitotic spindles were observed in nud mutants. This suggests that some of the nuclei of nud mutants do not reach the late stage of cell division at normal temperatures.
\end{abstract}

\section{INTRODUCTION}

Aspergillus nidulans is a filamentous fungus of considerable biological interest and importance that provides an excellent model system for genetic and biochemical analysis of microtubule-associated functions (MartinezRossi and Azevedo, 1989a,b; Andrade-Monteiro et al., 1994), among them mitosis and nuclear migration.

Microtubules are filaments composed of dimers of alpha- and beta-tubulins implicated in a variety of functions, including ciliary and flagellar movements, cell motility and cytoplasmic streaming, nucleus and chromosome movement, maintenance of cell shape, intracellular and axoplasmic transport, and anchorage of cell surface receptors (Mandelkow and Mandelkow, 1994). Microtubules are usually capable of being rapidly assembled and disassembled and it is known from early microscope studies that they are not arranged randomly in cells but are organized around one or more discrete foci (Porter, 1966) called microtubule organizing centers (MTOCs) (Brinkley, 1985; Oakley, 1994). MTOCs bind to microtubules and microtubule proteins, and assembly of microtubules preferentially occurs at these centers over other regions of the cytoplasm (Koshland, 1994). Although the function of MTOCs as nucleating centers for microtubules seems to be well established, there are reports of filamentous fungi in which microtubules have been noted not to be associated with MTOCs (O'Donnell and McLaughlin, 1981; Hoch and Staples, 1985).

Nuclear migration plays an important role in the growth and development of both higher and lower eukaryotes. In A. nidulans, nuclear migration is required for proper nuclear distribution throughout the mycelium and for the entry of nuclei into sexual spore generation structures (ste-

Departamento de Genética, Faculdade de Medicina de Ribeirão Preto, Universidade de São Paulo, Av. Bandeirantes, 3900, 14049-900 Ribeirão Preto, SP, Brasil. Send correspondence to N.M.M.-R. rigmata) and asexual spores (conidia) (Morris and Enos, 1992; Willins et al., 1995). Morris (1976) isolated a unique class of recessive temperature-sensitive mutants of $A$. nidulans that specifically affect nuclear movement. At the restrictive temperature $\left(42^{\circ} \mathrm{C}\right)$, strains carrying a $n u d$ (from $n u c l e a r$ istribution) mutation are unable to transport nuclei into growing mycelia and therefore have severely restricted growth and differentiation under these conditions. Genetic analysis of these mutants has identified four genes called $n u d A, n u d C$, nudF and nudG. Xiang et al. (1994) have shown that a microtubule-associated mechanochemical ATPase protein, cytoplasmic dynein, is involved in nuclear movement in A. nidulans. The nudA and nudG genes, respectively, encode the heavy and light chain of cytoplasmic dynein (Xiang et al., 1995b; Chiu et al., 1997). $n u d F$ encodes a protein acting on the dynein motor system (Willins et al., 1997), whose amino acid sequence is $42 \%$ identical to that of the human LIS1 protein, which is required for neuronal migration during brain development (Xiang et al., 1995a). nudC encodes a protein required for nuclear migration whose function is connected with that of the NUDF protein (Osmani et al., 1990; Chiu and Morris, 1995; Xiang et al., 1995a; Chiu et al., 1997). Also, deletion of $n u d \mathrm{C}$ profoundly affects the morphology and composition of the cell wall (Chiu et al., 1997).

An important step in the understanding of the nuclear migration process in A. nidulans is the visualization of the microtubule cytoskeleton as well as the characterization of putative MTOCs in this fungus. We carried out block/release experiments to depolymerize and repolymerize microtubules by using the antimicrotubule drug Benomyl in order to understand the microtubule nucleation process in A. nidulans germlings. We also tried to determine whether the cytoplasmic microtubules or mitotic spindles are affected by, or are somehow involved in, the blockage of nuclear migration of $n u d$ mutants of $A$. nidulans, since nuclear movement has been shown to be dependent on microtubules in this fungus. 


\section{MATERIAL AND METHODS}

\section{Cytoskeleton analysis of $\mathbf{n u d}$ mutants}

The nud mutants used were XX3 (nudAl chaAl pyrG89), A01 (nudC3 pabaAl nicAl pyrG89 wA2 chaAl), XX20 (nudF6 pyrG89) and SB05.10 (nudG8 yA2 pabaAl). The cytoskeleton structure of microtubules of $n u d$ mutants and the control strain R21 (yA2 pabaAl) of A. nidulans was observed by indirect immunofluorescence microscopy. Asexual spores of nud mutants and of R21 strain were inoculated into $\mathrm{YG}$ liquid medium for $7 \mathrm{~h}$, at $37^{\circ} \mathrm{C}$. The germlings were then rinsed in PEM $\{50 \mathrm{mM}$ PIPES (piperazine-N,N'-bis [2-ethanesulfonic acid]; 1,4-piperazinediethanesulfonic acid), $25 \mathrm{mM}$ EGTA (ethylene glycolbis( $\beta$-aminoethyl ether)N,N,N',N'-tetraacetic acid), $5 \mathrm{mM}$ $\left.\mathrm{MgSO}_{4}, \mathrm{pH} 6.7\right\}$ and fixed in $8 \%$ formaldehyde in PEM buffer containing 5\% DMSO (dimethyl sulfoxide) and 15 $\mathrm{mM} \mathrm{NaOH}$ for $60 \mathrm{~min}$ at room temperature. After this period the germlings were rinsed in PEM and stained for tubulin.

The parameters used to determine the possible differences between the mutants and the control strain were mitotic index, number and size of mitotic spindles, and presence of astral microtubules.

\section{Benomyl block and release experiments}

The medium used was YG ( $2 \%$ glucose, $0.5 \%$ yeast extract, and trace elements). Trace elements were as described by Kafer (1977). For tubulin staining, asexual spores (conidia) of A. nidulans strain R21 were inoculated onto coverslips. After $7 \mathrm{~h}$ of incubation at $37^{\circ} \mathrm{C}$, coverslips with adherent germlings were transferred to Petri dishes containing YG plus $2.4 \mu \mathrm{g} / \mathrm{ml}$ of Benomyl (Bonide Chemical Co., Yorkville, NY, USA) and incubated for periods of 1,2, 5, 10, 20 or $90 \mathrm{~min}$ at room temperature for microtubule depolymerization. Benomyl was dissolved in absolute ethanol $(2 \mathrm{mg} / \mathrm{ml})$. After drug treatment the germlings were briefly rinsed in PEM and fixed in $8 \%$ formaldehyde as described earlier. After $60 \mathrm{~min}$ at room temperature the germlings were rinsed in PEM and stained for indirect immunofluorescence microscopy. Following exposure to Benomyl for $90 \mathrm{~min}$, the germlings were reincubated in liquid medium without Benomyl at room temperature for $10,20,30,40$, or $50 \mathrm{~s}$ for microtubule repolymerization. The germlings were fixed as described above and stained for tubulin.

\section{Tubulin staining and microscopy}

To remove the cell wall, the coverslips were incubated in $100-\mu 1$ drops of novozyme solution (1\% lysing enzyme, $2.5 \%$ driselase, $50 \%$ egg white, 2 mM EGTA, 10 $\mu \mathrm{g} / \mathrm{ml}$ aprotinin, $1 \mathrm{mM}$ TAME, $100 \mu \mathrm{g} / \mathrm{ml}$ soybean trypsin inhibitor, $10 \mu \mathrm{g} / \mathrm{ml}$ leupeptin, and $10 \mu \mathrm{g} / \mathrm{ml}$ pepstatin) for
90 min at $28^{\circ} \mathrm{C}$. After novozyme digestion, the coverslips were washed in PEM and then extracted with $0.2 \%$ NP40, and 10\% DMSO in PEM for 1 min at room temperature. The cells were washed free of extraction buffer using PEM and then stained for tubulin.

Tubulin staining was carried out according to Oakley et al. (1990), with some modifications. Primary (anti- $\alpha$-tubulin DM 1A mouse monoclonal antibody, SIGMA) and secondary (anti-mouse CY3 conjugated, Jackson Immunoresearch Laboratory, Inc.) antibodies were diluted in PEM containing 3\% BSA. The coverslips were incubated with the first antibody for $1 \mathrm{~h}$ at $28^{\circ} \mathrm{C}$ and then washed in PEM and reincubated with the second antibody for $1 \mathrm{~h}$ at $28^{\circ} \mathrm{C}$ in the dark. For nuclear staining the coverslips were washed in PEM and incubated in DAPI solution ( $1 \mu \mathrm{g} / \mathrm{ml}$ in PEM buffer) for $5 \mathrm{~min}$ at room temperature in the dark. The coverslips were then washed in PEM, mounted in Citiflour and examined with a Zeiss epifluorescence microscope.

\section{RESULTS AND DISCUSSION}

Since nuclear movement has been shown to be dependent on microtubules in A. nidulans, we analyzed whether mutants defective in nuclear distribution along the growing hyphae (nud mutants) had some obvious microtubule defect. We verified that cytoplasmic, astral and spindle microtubules are present and appear to be normal in all nud mutants (Figure 1). However, we detected a difference in the percentage of short and long mitotic spindles in $n u d$ mutants (nudA, $C$ and $F$ ), when compared with a control strain (Table I). This indicates that some of the nuclei of these nud mutants do not reach the late stage of cellular division (telophase) at non-restrictive temperature.

To learn more about the microtubule nucleation process in A. nidulans germlings we used the antimicrotubule drug Benomyl in block/release experiments to depolymerize and repolymerize microtubules. Microscopic observation of the treated germlings after 40 to $90 \mathrm{~min}$ of exposure to Benomyl $(2.4 \mu \mathrm{g} / \mathrm{ml})$ showed that they are completely depleted of microtubules (Figure 2B). To allow microtubule repolymerization and to observe regions of microtubule nucleation in A. nidulans, germlings previously exposed to Benomyl for $90 \mathrm{~min}$ were transferred to Benomyl-free YG medium. The repolymerization of microtubules was microscopically observed for different periods of time (Figure 3B to F). Most of the germlings were in mitosis and their mitotic spindles had been formed from regions surrounding the nuclei (data not shown). Short microtubules were observed $20 \mathrm{~s}$ after release from Benomyl (Figure 3C). They appeared to have been formed from bright (immunofluorescent) dots randomly distributed along the germlings. Microtubule arrays regained their original profiles $50 \mathrm{~s}$ after Benomyl release (Figure 3F). These results strongly indicate that microtubule nucleation 

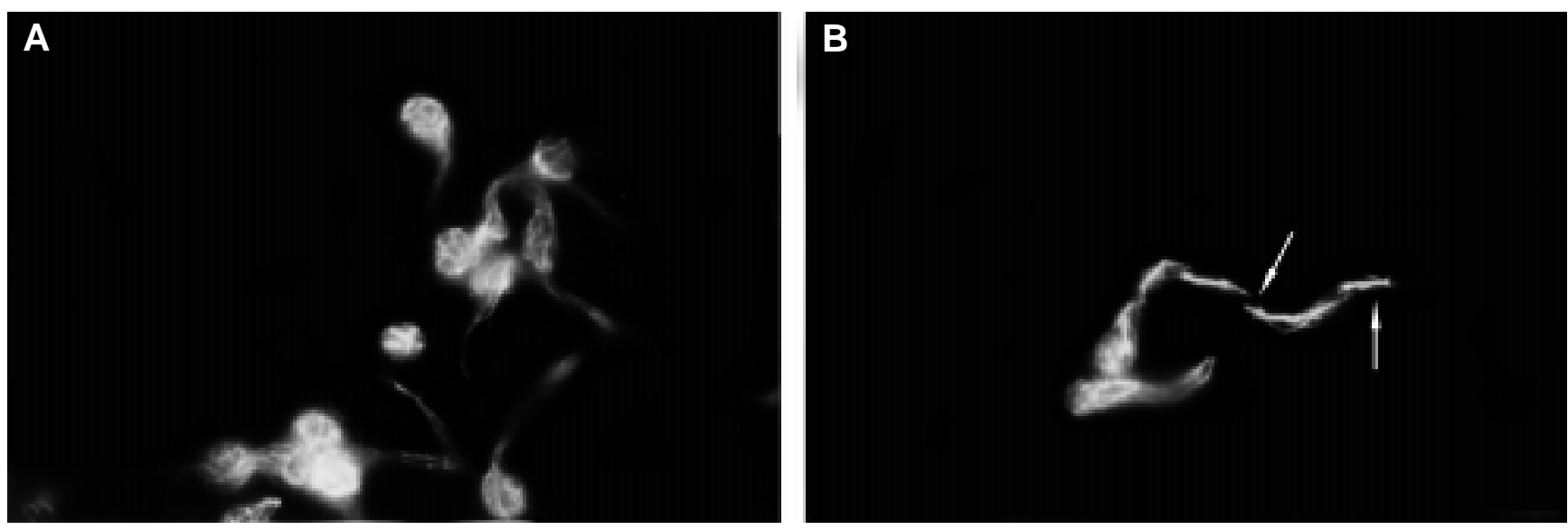

Figure 1 - Indirect immunofluorescence microscopy of microtubule cytoskeleton structure and DAPI staining of the XX20 mutant (A) and control strain R21 (B) of Aspergillus nidulans; mitotic spindle and astral microtubules are seen (arrows).

Table I - Percentage of long and short mitotic spindles in nud mutants and in the control strain R21 of Aspergillus nidulans.

\begin{tabular}{|llc|}
\hline \multirow{2}{*}{$\begin{array}{l}\text { Strains } \\
\text { (relevant genotype) }\end{array}$} & \multicolumn{2}{c|}{ Mitotic spindles (\%) } \\
\cline { 2 - 3 } & long & short \\
\hline R21 & 48.25 & 51.75 \\
XX3(nudA1)* & 20.54 & 79.46 \\
AO1(nudC3)* & 17.95 & 82.05 \\
XX20(nudF6)* & 19.27 & 80.73 \\
SB05.10(nudG8) & 37.50 & 62.50 \\
\hline
\end{tabular}

*Significantly different from R21. P 0.05 ( $\chi^{2}$ test $)$.

is randomly distributed along A. nidulans germlings, in contrast to Hoch and Staples (1985), who found that the microtubule nucleating region is in the hyphal apex of the fungus Uromyces phaseoli. Roberson and Vargas (1994) also verified that structures present at the hyphal apex ("Spitzenkörper") and in centrosomes function as centers of microtubule nucleation and organization during hyphal tip growth in Allomyces macrogynus. Although microtubules are generally thought to originate at the centrosome, a number of cell types have significant populations of microtubules with no apparent centrosomal connection, and the origin of these noncentrosomal microtubules has been unclear (Karsent et al. 1984; Keating et al., 1997).

Early electron microscope studies have suggested that microtubules are not randomly arranged in cells but are organized around one or more discrete foci (Porter, 1966; Brinkley, 1985). In fungi, they are called spindle pole bodies (SPBs), an organelle associated with the nucleus. In A. nidulans, there is some evidence that some microtubules may begin and end independent of the SPBs (Berl Oakley, personal communication). In Saccharomyces cerevisiae, a tubulin encoded by the TUB4 gene and related to $\gamma$-tubulin seems to be involved in nucleation processes of microtubules that grew from, or that remained attached to SPBs (Marschall et al., 1996). Are the bright dots observed in our repolymerization experiments MTOCs for A. nidulans? We cannot rule out the possibility that
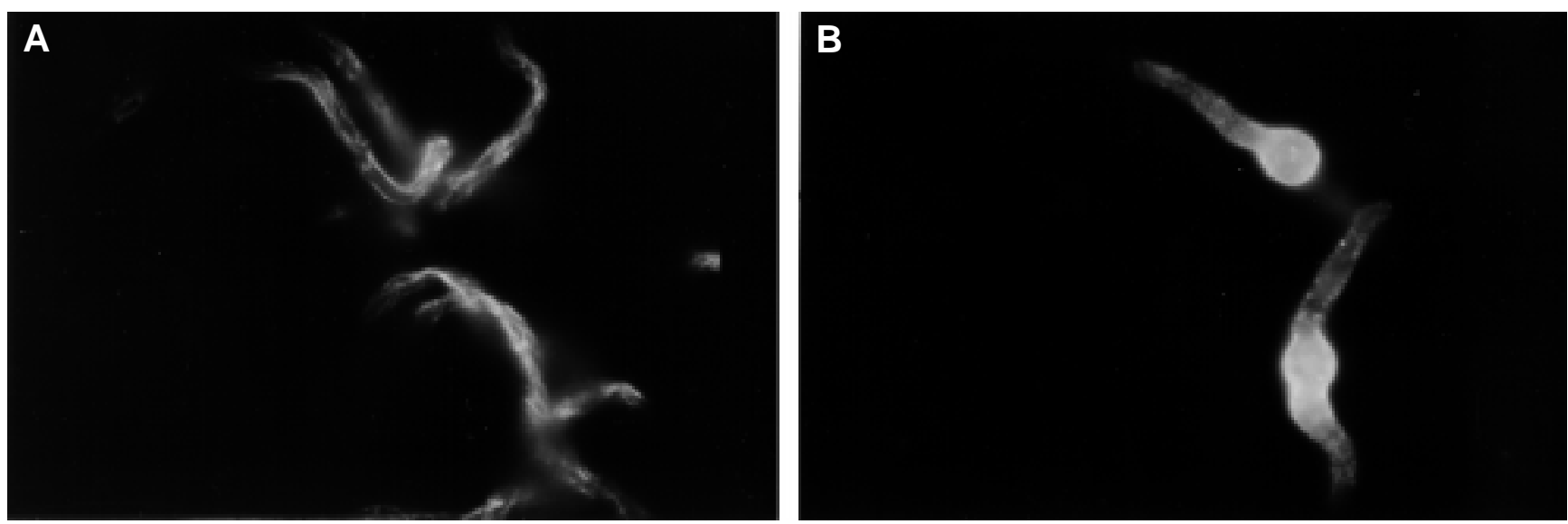

Figure 2 - Indirect immunofluorescence microscopy of the microtubule cytoskeleton structure in control (A) and in germlings of R21 strain of Aspergillus nidulans exposed to Benomyl for $90 \mathrm{~min}$ (B). Note the depolymerization of microtubules in Benomyl-treated germlings. 

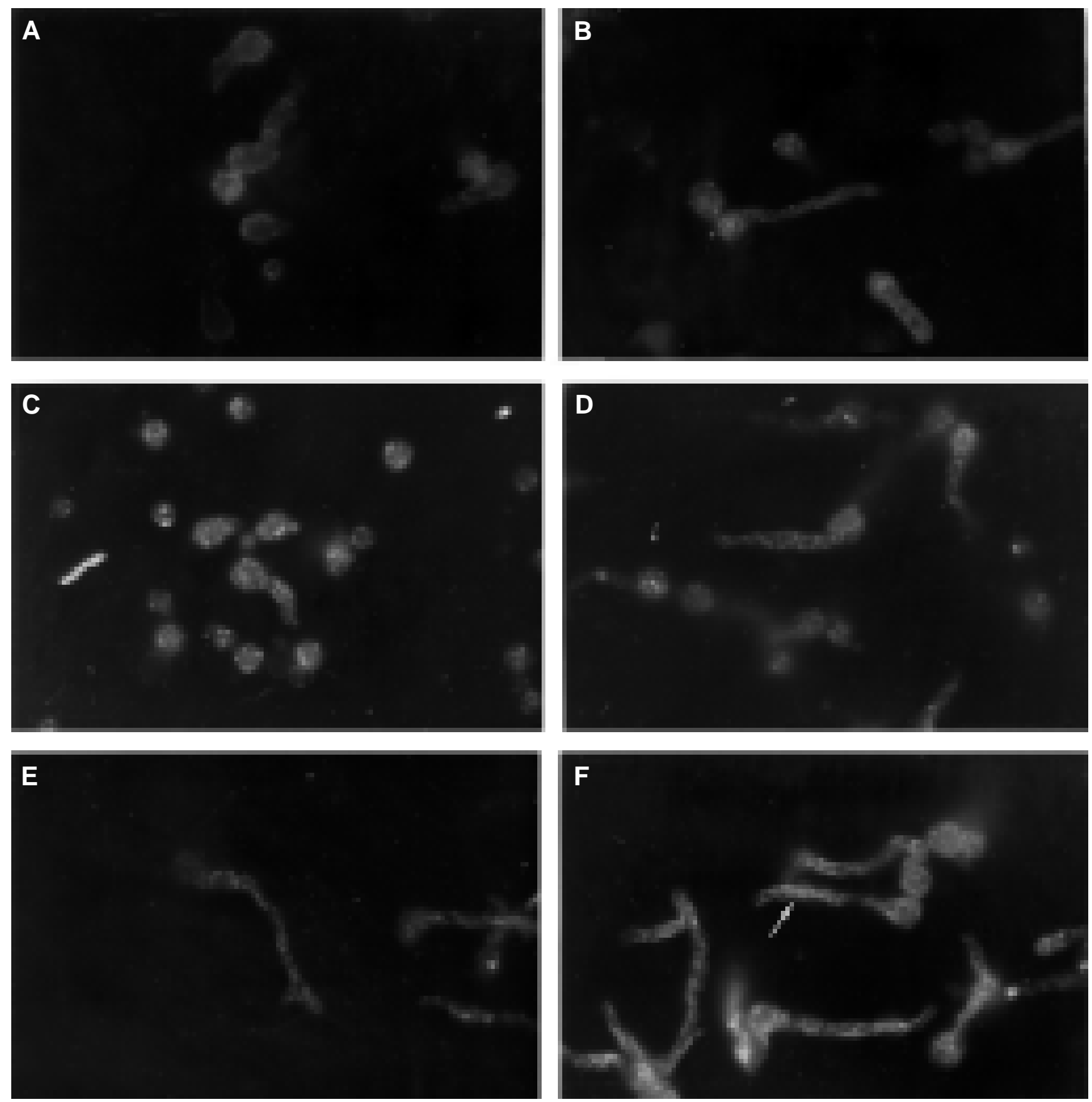

Figure 3 - Microtubule repolymerization of germlings of R21 strain of Aspergillus nidulans previously exposed to Benomyl for 90 min after transfer to Benomyl free-medium. Repolymerization was observed for different periods of time (B-F). A - Germlings without release from Benomyl. B-F - Microtubule (arrow) cytoskeleton repolymerization 10, 20,30, 40 and 50 s, respectively, after Benomyl release.

these dots are simply tubulins, tubulin-associated proteins or even microtubule fragments that remained as aggregates distributed through the cytoplasm after release from the drug. When subjected to repolymerization they could assemble. In contrast to this hypothesis, there are many lines of experimental evidence indicating the repolymerization of microtubules in mammalian cells during recovery from inhibitors such as Colcemid, Nocodazole and cold temperature (De Brabander et al., 1981; Rieder and Borisy,
1981; Stearns et al., 1991), and showing that microtubule regrowth occurs in the centrosomes (Brinkley, 1985).

Since $\gamma$-tubulin is a protein localized in MTOC-like centrosomes (Stearns et al., 1991; Moritz et al., 1995), in SPBs (Oakley et al., 1990; Oakley, 1994) and is also related to microtubule nucleation both in vitro (Zheng et al., 1995) and in vivo (Moritz et al., 1995), immunofluorescence experiments using anti- $\gamma$-tubulin antibody would be a good approach to verify whether these bright dots are MTOCs. 


\section{ACKNOWLEDGMENTS}

We are deeply grateful to Dr. N. Ronald Morris, University of Medicine and Dentistry of New Jersey, Robert Wood Johnson Medical School (Piscataway, NJ, USA), for his warm hospitality during C.A.M.'s stay in his laboratory, where a substantial part of this work was carried out. C.A.M. was the recipient of a CAPES fellowship. We thank Mrs. Elettra Greene for revising the manuscript. Publication supported by FAPESP.

\section{RESUMO}

Microtúbulos são filamentos compostos por dímeros das tubulinas $\alpha$ e $\beta$ e têm uma variedade de funções nas células vivas. Em fungos, os corpúsculos polares dos fusos são geralmente considerados os centros organizadores dos microtúbulos. Com o objetivo de contribuir para uma melhor compreensão dos processos de nucleação dos microtúbulos no fungo filamentoso A. nidulans, nós utilizamos a droga antimicrotúbulo Benomil em experimentos de bloqueio e liberação para depolimerizar e repolimerizar os microtúbulos. Após 20 segundos de reincubação em meio sem Benomil, pequenos microtúbulos foram formados a partir de pontos distribuídos pela célula, sugerindo que os pontos de nucleação de microtúbulos são aleatoriamente distribuídos pelas hifas de A. nidulans. Como em A. nidulans o movimento nuclear é dependente de microtúbulos foi analisado se mutantes defectivos na distribuição de núcleos ao longo das hifas (mutantes nud) possuíam algum defeito evidente nos microtúbulos. Os microtúbulos citoplasmáticos, dos fusos e astrais estão presentes e aparentam-se normais em todos os mutantes nud, mas foi observada uma pequena distorção na proporção de fusos mitóticos longos e curtos nestes mutantes, comparados com o controle. Isto sugere que alguns núcleos de mutantes nud não alcançam a fase tardia da divisão celular, em temperatura não restritiva.

\section{REFERENCES}

Andrade-Monteiro, C., Pombeiro-Sponchiado, S.R.C. and MartinezRossi, N.M. (1994). The effect of gene $t u b C$ on the vegetative growth of Benomyl-resistant strains of Aspergillus nidulans. FEMS Microbiol. 120: 183-186.

Brinkley, B.R. (1985). Microtubule organizing centers. Ann. Rev. Cell Biol. 1: $145-172$.

Chiu, Y.H. and Morris, N.R. (1995). Extragenic suppressors of nudC3, a mutation that blocks nuclear migration in Aspergillus nidulans. Genetics 141: 453-464.

Chiu, Y.H., Xiang, X., Dawe, A.L. and Morris, N.R. (1997). Delection of nudC, a nuclear migration gene of Aspergillus nidulans, causes morphological and cell wall abnormalities and is lethal. Mol. Biol. Cell 8: 1735-1749.

De Brabander, M., Geuens, G., De Mey, J. and Jonial, M. (1981). Nucleated assembly of mitotic microtubules in living PTK lease from Nocodazole treatment. Cell Motil. 1: 469-483.

Hoch, H.C. and Staples, R.C. (1985). The microtubule cytoskeleton in hyphae of Uromyces phaseoli germlings: its relationship to the regions of nucleation and to the F-actin cytoskeleton. Protoplasma 124: $112-122$.

Kafer, E. (1977). Meiotic and mitotic recombination in Aspergillus and its chromosomal aberrations. Adv. Genet. 19: 133-131.

Karsent, E., Kobayashi, S., Mitchison, T. and Kirschner, M. (1984). Role of the centrosome in organizing the interphase microtubule array: properties of cytoblasts containing or lacking centrosomes. J. Cell Biol. 98: 1763-1776.

Keating, T.J., Peloquin, J.G., Rodionov, V.I., Momcilovic, D. and Borisy, G.G. (1997). Microtubule release from the centrosome. Proc. Natl. Acad. Sci. USA 94: 5078-5083.

Koshland, D. (1994). Mitosis: Back to the basics. Cell 77: 951-954.

Mandelkow, E. and Mandelkow, E.M. (1994). Microtubule structure. Curr. Opin. Struct. Biol. 4: 171-179.

Marschall, L.G., Jeng, R.L., Mulholland, J. and Stearns, T. (1996). Analysis of Tub4p, a yeast $\gamma$-tubulin-like protein: implications for microtubule-organizing center function. J. Cell Biol. 134: 443-454.

Martinez-Rossi, N.M. and Azevedo, J.L. (1989a). Characterization of Benomyl resistant mutants of Aspergillus nidulans. Rev. Bras. Genét. 12: 477-484.

Martinez-Rossi, N.M. and Azevedo, J.L. (1989b). Additive effect involving a new locus of Benomyl resistance in Aspergillus nidulans. Fungal Genet. Newsl. 36: 51.

Moritz, M., Braunfeld, M.B., Sedat, J.W., Alberts, B. and Agard, D.A. (1995). Microtubule nucleation by $\gamma$-tubulin-containing rings in the centrosome. Nature 378: 638-640.

Morris, N.R. (1976). Mitotic mutants of Aspergillus nidulans. Genet. Res. 26: 237-254.

Morris, N.R. and Enos, A.P. (1992). Mitotic gold in a mold: Aspergillus genetics and the biology of mitosis. Trends Genet. 8: 32-37.

O'Donnell, K.L. and McLaughlin, D.J. (1981). Ultrastructure of meiosis in the hollyhock rust fungus, Puccinia malvacearum. I. Prophase IPrometaphase I. Protoplasma 108: 225-244.

Oakley, B.R. (1994). $\gamma$-Tubulin. In: Microtubules (Hyams, J.S. and Lloyd, C.W., eds.). Wiley-Liss, Inc., New York, pp. 33-45.

Oakley, B.R., Oakley, C.E., Yoon, Y. and Jung, M.K. (1990). $\gamma$-Tubulin is a component of the spindle-pole-body that is essential for microtubule function in Aspergillus nidulans. Cell 61: 1289-1301.

Osmani, A.H., Osmani, S.A. and Morris, N.R. (1990). The molecular cloning and identification of a gene product specifically required for nuclear movement in Aspergillus nidulans. J. Cell Biol. 111: 543-551.

Porter, K.R. (1966). Cytoplasmic microtubules and their functions. In: Principles of Biomolecular Organization (Wolstenholme, G.E.W. and O'Connor, M., eds.). Churchill, London, pp. 308-345.

Rieder, C.L. and Borisy, G.G. (1981). The attachment of kinetochores to the prometaphase spindle in Ptk cells. Recovery from low temperature treatment. Chromosoma 82: 693-716.

Roberson, R.W. and Vargas, M.M. (1994). The tubulin cytoskeleton and its sites of nucleation in hyphal tips of Allomyces macrogynus. Protoplasma 182: 19-31.

Stearns, T., Evans, L. and Kirschner, M. (1991). $\gamma$-Tubulin is a highly conserved component of the centrosome. Cell 65: 825-836.

Willins, D.A, Xiang, X. and Morris, N.R. (1995). An alpha tubulin mutation suppresses nuclear migration mutations in Aspergillus nidulans. Genetics 141: 1287-1298.

Willins, D.A., Liu, B., Xiang, X. and Morris, N.R. (1997). Mutations in heavy chain of cytoplasmic dynein suppress the $n u d F$ nuclear migration mutation of Aspergillus nidulans. Mol. Gen. Genet. 255: 194200.

Xiang, X., Beckwith, S.M. and Morris, N.R. (1994). Cytoplasmic dynein is involved in nuclear migration in Aspergillus nidulans. Proc. Natl. Acad. Sci. USA 91: 2100-2104.

Xiang, X., Osmani, A.H., Osmani, S.A., Xin, M. and Morris, N.R. (1995a). $N u d \mathrm{~F}$, a nuclear migration gene in Aspergillus nidulans, is similar to the human LIS-1 gene required for neuronal migration. Mol. Biol. Cell 6: 297-310

Xiang, X., Roghi, C. and Morris, N.R. (1995b). Characterization and localization of cytoplasmic dynein heavy chain in Aspergillus nidulans. Proc. Natl. Acad. Sci. USA 92: 9890-9894.

Zheng, Y., Wong, M.L., Alberts, B. and Mitchison, T. (1995). Nucleation of microtubule assembly by a $\gamma$-tubulin-containing ring complex. Nature 378: 578-583.

(Received June 9, 1998) 
